\title{
Straw production and agronomic performance of soybean intercropped with forage species in no-tillage system
}

\author{
Carlos Augusto Oliveira de Andrade(1), Emerson Borghi(2), Leandro Bortolon ${ }^{(3)}$, \\ Elisandra Solange Oliveira Bortolon ${ }^{(3)}$, Francelino Peteno de Camargo ${ }^{(3)}$, Junior Cesar Avanzi ${ }^{(4)}$, \\ Jones Simon ${ }^{(3)}$, Rubens Ribeiro da Silva ${ }^{(1)}$ and Rodrigo Ribeiro Fidelis ${ }^{(1)}$
}

\begin{abstract}
(1)Universidade Federal do Tocantins, Rua Badejós, Lote 7, Chácaras 69/72, Zona Rural CEP 77402-970 Gurupi, TO, Brazil. E-mail: carlosandradeuft@hotmail.com, rrs2002@mail.uft.edu.br, fidelisrr@mail.uft.edu.br (2)Embrapa Milho e Sorgo, Rodovia MG-424, Km 65, CEP 35701-970 Sete Lagoas, MG, Brazil. E-mail: emerson.borghi@embrapa.br ${ }^{(3)}$ Embrapa Pesca e Aquicultura, Prolongamento da Avenida NS 10, Cruzamento com a Avenida LO 18, Sentido Norte, Loteamento Água Fria, CEP 77008-900 Palmas, TO, Brazil. E-mail: leandro. bortolon@embrapa.br, elisandra.bortolon@embrapa.br, francelino.camargo@embrapa.br, jones.simon@embrapa.br (4)Universidade Federal de Lavras, Departamento de Ciência do Solo, Avenida Doutor Sylvio Menicucci, oo 1001, Kennedy, CEP $37200-000$ Lavras, MG, Brazil. E-mail: junior.avanzi@dcs.ufla.br
\end{abstract}

\begin{abstract}
The objective of this work was to evaluate the straw production and the agronomic performance of soybean intercropped with oversown forage species, in no-tillage system. A randomized complete block design was carried out with four replicates, in a $5 \times 2+2$ factorial arrangement, as follows: five forage species - Urochloa brizantha 'Marandu', Urochloa ruziziensis, Panicum maximum 'Mombaça', Panicum maximum 'Massai', and Pennisetum americanum -, intercropped with soybean over two crop years (2013/2014 and 2014/2015), plus two controls, with P. americanum sowed in succession to soybean or with soybean monocropping followed by winter fallow (traditional cultivation). Soybean yield components and forage straw yield were evaluated. None of the intercropping systems reduced soybean grain yield, compared with monocropped soybean. The oversown species can significantly improve soybean productivity, as is the case for soybean intercropped with P. maximum 'Mombaça', compared with soybean monocropping, followed or not by millet. Panicum maximum 'Mombaça' is the most effective forage species for dry matter accumulation in the fall/spring period.
\end{abstract}

Index terms: Glycine max, integrated crop-livestock system, oversowing, plant cover, soil cover crops.

\section{Produção de palha e desempenho agronômico de soja consorciada com espécies forrageiras em sistema plantio direto}

Resumo - O objetivo deste trabalho foi avaliar a produção de palha e o desempenho agronômico de soja consorciada com espécies forrageiras sobressemeadas, em sistema plantio direto. Utilizou-se um delineamento de blocos ao acaso, com quatro repetições, em um arranjo fatorial $5 \times 2+2$, conforme a seguir: cinco espécies forrageiras - Urochloa brizantha 'Marandu', Urochloa ruziziensis, Panicum maximum 'Mombaça', Panicum maximum 'Massai' e Pennisetum americanum - consorciadas com soja, em duas safras agrícolas (2013/2014 e 2014/2015), além de dois tratamentos-padrão, com P. americanum em sucessão à soja ou com cultivo tradicional de soja e pousio no inverno (soja solteira). Avaliaram-se os componentes de produção da soja e a produtividade de palha das forrageiras. Nenhum dos consórcios diminuiu a produtividade de grãos da soja, em comparação ao cultivo solteiro. As espécies sobressemeadas podem aumentar significativamente a produtividade da soja, como no caso do consórcio da soja com P. maximum 'Mombaça' comparado ao cultivo da soja solteira, com ou sem milheto em sucessão. Panicum maximum 'Mombaça' é a espécie forrageira mais eficiente quanto ao acúmulo de matéria seca, no período outono/primavera.

Termos para indexação: Glycine max, integração lavoura-pecuária, sobressemeadura, cobertura vegetal, cultivos de cobertura do solo.

\section{Introduction}

No-tillage and integrated crop-livestock systems are alternative methods for soil management that maintain, or even increase soil use efficiency with a more rational use of farming resources (Santos et al., 2008). In tropical climates, the no-tillage system is particularly important for soil conservation, and for maintaining soil productive capacity (Marchão et al., 2007). However, an adequate soil cover using straw species is 
required for this system to function efficiently (Calvo et al., 2010; Correia \& Gomes, 2015). To prevent soil from erosion, these soil cover species should have a high-phytomass yield and remain for a certain time on soil surface (Kliemann et al., 2006), in order to favor a greater retention of moisture during water deficit conditions and to make nutrients available to crops in succession, or even to provide pasture during the offseason (Flores et al., 2008; Pariz et al., 2011).

Various crops for straw production and soil coverage have been tested for use in fall/winter periods, in no-tillage system, in the Cerrado region of the state of Mato Grosso do Sul, Brazil (Machado \& Assis, 2010). Among the most promising species are bulrush millet (Pennisetum americanum), grain sorghum or forage sorghum (Sorghum bicolor), and tropical forage grasses, in particular species from the genera Urochloa and Panicum (Macedo, 2009), which can be optionally intercropped with the primary crop. These species produce a large quantity of dry matter, with straw of high potential to cover soil for an extended period, even in hotter regions (Costa, 2014), such as the Cerrado region in the Brazilian state of Tocantins.

The smaller size and competitive power of certain primary crops, in comparison to these forage species, makes it unsuitable to sow them at the same time. Moreover, the greater vegetative growth of the forage species can make harvesting the primary crop more difficult (Vilela et al., 2011). Therefore, oversowing soybean plants with forage species before flowering, specifically during the reproductive stages R5, R6, or R7, could make intercropping viable (Pacheco et al., 2009, 2013; Silva et al., 2013).

The objective of this work was to evaluate the straw production and the agronomic performance of soybean intercropped with oversown forage species, in a no-tillage system.

\section{Materials and Methods}

The experiment was carried out at Fazenda Experimental of Universidade Federal de Tocantins (11 $43^{\prime} 45^{\prime \prime} \mathrm{S}, 49^{\circ} 04^{\prime} 07^{\prime \prime} \mathrm{W}$, at 278 maltitude), during the 2012/2013, 2013/2014, and 2014/2015 crop years.

Before the experiment began, soil samples were collected at $0-0.20 \mathrm{~m}$ soil depths, and their chemical analysis showed the following results: $\mathrm{pH}\left(\mathrm{CaCl}_{2}\right), 3.98$; $\mathrm{P}, 1.09 \mathrm{mg} \mathrm{dm}^{-3} ; \mathrm{K}, 32.0 \mathrm{mg} \mathrm{dm}^{-3} ; \mathrm{Cu}, 0.90 \mathrm{mg} \mathrm{dm}^{-3} ; \mathrm{Zn}$,
$0.30 \mathrm{mg} \mathrm{dm}^{-3} ; \mathrm{Mn}, 12.20 \mathrm{mg} \mathrm{dm}^{-3} ; \mathrm{Ca}, 0.17 \mathrm{cmol}_{\mathrm{c}} \mathrm{dm}^{-3}$; $\mathrm{Mg}, \quad 0.06 \mathrm{cmol}_{\mathrm{c}} \quad \mathrm{dm}^{-3} ; \mathrm{Al}, \quad 0.75 \mathrm{cmol}_{\mathrm{c}} \mathrm{dm}^{-3}$; $\mathrm{H}+\mathrm{Al}, 4.34 \mathrm{cmol}_{\mathrm{c}} \mathrm{dm}^{-3}$; effective CEC (t), $1.06 \mathrm{cmol}_{\mathrm{c}}$ $\mathrm{dm}^{-3}$; CEC (T), $4.65 \mathrm{cmol}_{\mathrm{c}} \mathrm{dm}^{-3}$; Al saturation (m), $70.75 \%$; basis saturation (BS), 6.71\%; and organic matter, $15.40 \mathrm{~g} \mathrm{dm}^{-3}$. The granulometric analysis showed $690 \mathrm{~g} \mathrm{dm}^{-3}$ sand, $100 \mathrm{~g} \mathrm{dm}^{-3}$ silt, and $210 \mathrm{~g} \mathrm{dm}^{-3}$ clay (Claessen, 1997). Based on these results, $2,500 \mathrm{~kg} \mathrm{ha}^{-1}$ limestone and $1,000 \mathrm{~kg} \mathrm{ha}^{-1}$ gypsum were applied on Andropogon gayanus residues remaining in the area, in the first 15 days of December 2012. In addition, $250 \mathrm{~kg} \mathrm{ha}^{-1} \mathrm{P}_{2} \mathrm{O}_{5}$, in the form of single superphosphate, and $100 \mathrm{~kg} \mathrm{ha}^{-1} \mathrm{~K}_{2} \mathrm{O}$, in the form of $\mathrm{KCl}$, were applied to the soil surface. Dolomite limestone was used as a filler (100\% PRNT) to increase the soil base saturation to $60 \%$, according to Sousa \& Lobato (2004).

The soil was prepared on December 16, 2012, using a 32-inch grid to incorporate plaster at $0-0.40 \mathrm{~m}$ soil depths. The remaining fertilizers and correctors that were applied over the entire area made use of a 28 -inch grid, incorporated to soil at $0-0.20 \mathrm{~m}$ depths.

Data for rainfall and maximum and minimum temperatures over the experiment were recorded at the Estação Meteorológica of the Universidade Federal de Tocantins, in the Campus Gurupi (Figure 1).

Forage species were manually sowed on the surface, on April 5, 2013, and dried on November 1, 2013 using glyphosate herbicide, at $1.8 \mathrm{~kg} \mathrm{ha}^{-1}$ a.e., and $200 \mathrm{~L} \mathrm{ha}^{-1}$ application volume. Thus, the 2012/2013 crop year was used strictly for forage straw production, to achieve an adequate no-tillage system for soybean yield in the 2013/2014 crop year.

The experiment was performed in a Latossolo Amarelo distrófico (Xanthic Oxisol) exhibiting a medium texture (Santos et al., 2013a). A randomized complete block design was used with four replicates, and a $5 \times 2+2$ factorial arrangement, with five forage species ( $U$. brizantha 'Marandu', U. ruziziensis, $P$. maximum 'Mombaça', $P$. maximum 'Massai', and $P$. americanum 'ADR 300') intercropped with soybean, over two crop years (2013/2014, and 2014/2015). Besides, two controls were employed: $P$. americanum sowed after soybean cultivation; and a monocropped soybean cultivation followed by winter fallow.

Each experimental unit consisted of ten soybean rows $21-\mathrm{m}$ long, spaced at $0.45 \mathrm{~m}$. The four central lines of each unit were evaluated, leaving $1.0 \mathrm{~m}$ as border at the ends of each line, in a $94.5 \mathrm{~m}^{2}$ total area. 
Early cycle soybean cultivar SYN1279 RR was used for both crop years. At the moment of sowing, seed were inoculated with the Bradyrhizobium japonicum Semia 5079 and Semia 5080, at $300 \mathrm{~g}$ for every $50 \mathrm{~kg}$ of seed.
In addition, $120 \mathrm{~kg} \mathrm{ha}^{-1} \mathrm{P}_{2} \mathrm{O}_{5}$, in the form of single superphosphate, was applied on the sowing lines, while $30 \mathrm{~kg} \mathrm{ha}^{-1}$ of FTE BR 12 was added to provide micronutrients. The soil was fertilized with potassium 10 days before soybean sowing, using $80 \mathrm{~kg} \mathrm{ha}^{-1} \mathrm{~K}_{2} \mathrm{O}$ in
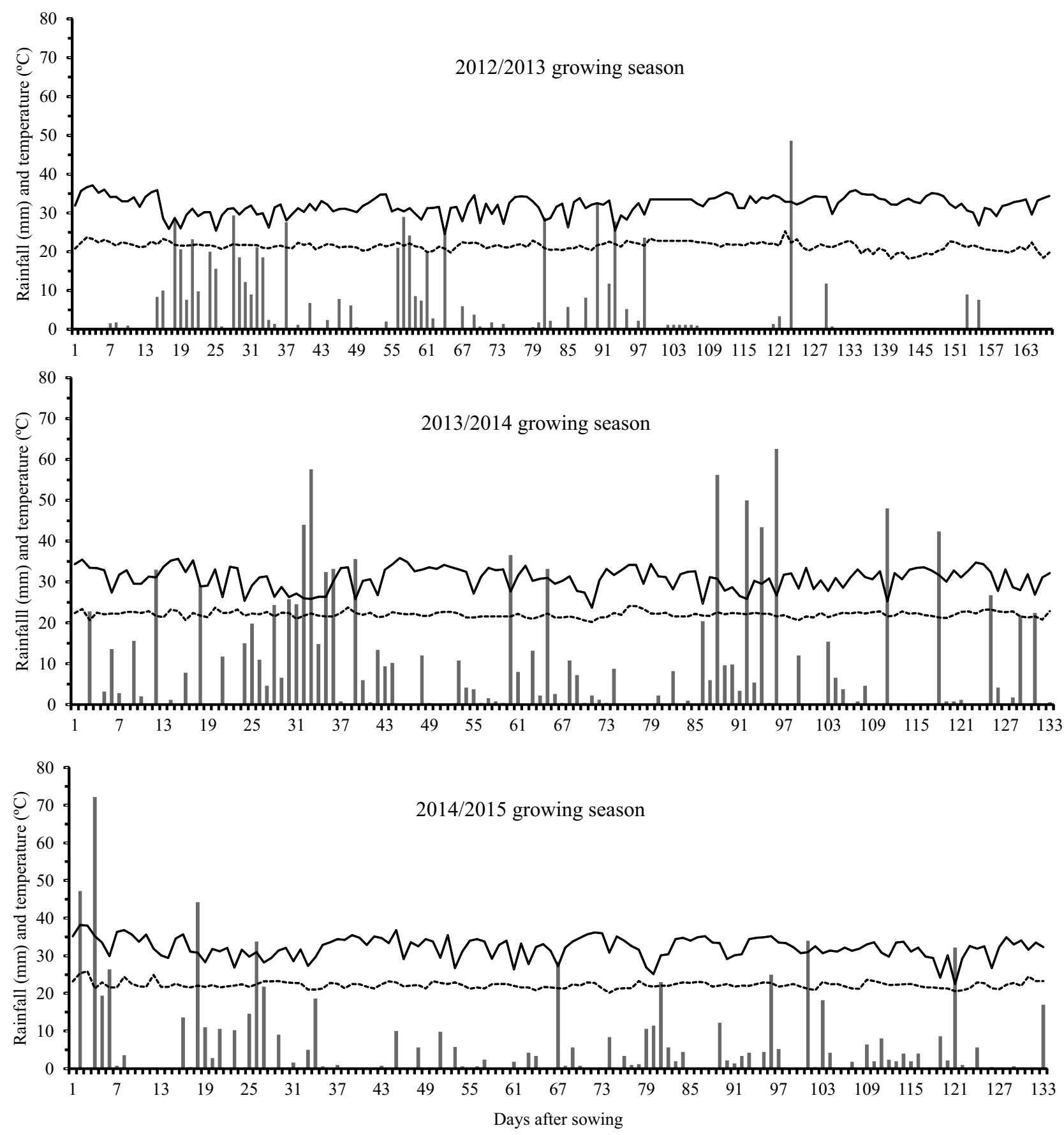

Rainfall $\quad$ Maximum temperature

Minimum temperature

Figure 1. Daily rainfall and minimum and maximum temperatures during the experiment in the 2012/2013, 2013/2014, and 2014/2015 crop years. 
the form of potassium chloride. Soybean was sown on November 20, with $0.45 \mathrm{~m}$ between lines and 17 plants per meter. The same planting date and spacing were used for both seasons.

Oversowing of forage species was completed manually once soybean plants reached the reproductive stage R5, defined as the point at which $50 \%$ of the plants show pod filling. Sowing densities recommended by Machado \& Assis (2010) were used. The specific online sowing values were $5 \mathrm{~kg} \mathrm{ha}^{-1}$ for viable pure seeds, except for $P$. americanum whose value was $15 \mathrm{~kg} \mathrm{ha}^{-1}$. In order to determine the exact quantity of seed to be used, the culture value of each species was taken into consideration (Pacheco et al., 2008).

Before soybean sowing, the phytomass of forage species sowed in the preceding season was quantified for each experimental unit $\left(\mathrm{kg} \mathrm{ha} \mathrm{h}^{-1}\right)$, using four randomly selected rectangular samples $(1.0 \times 0.25 \mathrm{~m})$. Dry matter yield per hectare was estimated by placing the samples in a forced-air circulation oven at $60^{\circ} \mathrm{C}$, until the obtention of constant mass. Forage species desiccation was performed with $1.8 \mathrm{~kg} \mathrm{ha}^{-1}$ glyphosat a.e., with $200 \mathrm{~L} \mathrm{ha}^{-1}$ spray solution.

The following components related to soybean yield were evaluated: plant height $(\mathrm{cm})$, from the stem base to the apex of the plant, measured in ten plants chosen at random from the useful area within each plot; final plant population, determined on March 18, in the eve of harvest in both years, by counting the number of plants within $3 \mathrm{~m}$ of the two central lines of each experimental unit; number of pods per plant, and their relation to the total number of plants within the useful area of each experimental unit, determined in ten plants harvested at random; number of grain per pod, determined using the total number of grain and pods obtained for these ten plants; mass of 100 grains, obtained by four separate weighings of 100 grains for each plot; and grain yield, determined within $3 \mathrm{~m}$ of the two central lines of each experimental unit. Plants were harvested manually, then dried and subjected to mechanical threshing. Afterward, grains were weighed to determine yield, with values corrected for $13 \%$ of moisture content.

The data were subjected to the analysis of variance, and the means were compared using the Tukey's test, at $5 \%$ probability, with the aid of the computer software Sisvar (Universidade Federal de Lavras, Lavras, MG).

\section{Results and Discussion}

The interaction between the intercropping systems and crop years was significant for final population, number of pods per plant, number of grain per pod, and dry matter of residues (Table 1); therefore, the systems had different performances, depending on the evaluation year for these characters. However, plant height, mass of 100 grains, and grain yield were not significantly affected by this interaction.

The intercropping soybean and $P$. maximum 'Mombaça' was the only combination that showed a significantly greater value for soybean plant height than monocropped soybean (Table 2). This is most likely due to the greater quantity of straw produced from this forage species during the off-seasons. The amount of incident solar radiation would have been reduced due to the quantity of straw in the area, at the initial development of soybean, resulting in a etiolation of plants in their search for light (Muraishi et al., 2005).

Significant effects of crop years also occurred for height (Table 2), and the 2013/2014 season yielded the highest means, which might be attributed to the greater amount of rainfall in this first season, in comparison to the second one (Figure 1) when average rainfall was $48 \%$ of the observed in first crop year.

The treatments affected the final plant populations only in the first year (Table 2). The soybean intercropped systems, both with $P$. maximum 'Mombaça' and $U$. ruziziensis, differed significantly from the soybean monocroped and from soybean with $P$. americanum in succession (Table 2). Intercropped systems showed an immediate beneficial effect on the initial plant development, and yielded greater plant populations than the nonintercropped systems. Soil protection and water retention, afforded by forage straw on soil surface, may have provided better conditions for soybean germination and establishment. Krutzmann et al. (2013) found higher-soybean populations in areas with greater surface phytomass, especially for those derived from $U$. brizantha 'Marandu' and $P$. maximum 'Tanzânia'.

Although intercropping had a significant effect on the number of pods per plant, the number of grains per pod showed no effect (Table 2). Generally, the behavior of the number of pods per plant, in the first crop year, was similar to that of the number of grain per plant for the intercropped systems in both 
seasons. Crusciol et al. (2012) did not observe any effect from intercropping for U. brizantha 'Marandu' system on any yield components. The authors argued that a longer intercropping period could affect soybean development, which did not happen in the present study, since our intercropping period was even shorter (73 days).

As to the crop year, a greater number of pods per plant were observed in the first year, independently of the foraging species (Table 2), while the number of grain per pod in the first year was significant only for P. maximum 'Massai', U. brizantha 'Marandu', and $P$. americanum systems. The average improvement in performance for these treatments was approximately $43 \%$ for the number of pods per plant, and $17 \%$ for the number of grain per pod. The quantity and distribution of rainfall over the two crop years are certainly related to the observed results (Figure 1). According to Farias et al. (2010), the amount of required water for soybean cultivation to fulfill the physiological cycle is between 650 and $700 \mathrm{~mm}$ of rainfall. This means that the amount of rain observed in both years was sufficient; however, in the 2013/2014 season, rainfall was better distributed over the period of cultivation. Rainfall in the 2014/2015 season did not provide sufficient water for each of the reproductive stages. Water deficits were observed during the full flowering and grain filling stages, which are the two stages during which soybean demands the most water. In this work, those stages corresponded to 45 and 103 days after sowing, respectively.

The demand for water increases progressively as crop development proceeds, peaking at the full flowering stage, which extends until the beginning of pod development; nonetheless, water demand remains high through physiological maturation (Thomas \& Costa, 2010). Thus, from a physiological vantage point, soybean tends to consume more water as the plant ages, showing minimal sensitivity during the vegetative phase and maximum sensitivity during the reproductive phase (Santos et al., 2013b).

Crop years had also a significant effect for the mass of 100 grains (Table 2), whose largest values were observed in the second season. In the first season, values ranged from 16.02 to $17.20 \mathrm{~g}$ among the different intercropped systems, while in the second season values ranged from 18.50 to $23.16 \mathrm{~g}$. However, none of the variations was statistically significant. Pacheco et al. (2009) also observed no significant variation in this parameter, when they studied soybean cultivated over straw produced from different plants. The observed difference between crop years, for this parameter, could be explained by the inverse relation that it showed with the number of pods per plant. Thus, the lower number of pods per plant in the second season favored the increase of soybean grain mass, as the drain represented by seeds was lower.

As to grain yield, the $P$. maximum 'Mombaça' system differed significantly from the $P$. americanum one, and from the monocropped trials followed either by fallow or by $P$. americanum cultivation. These results, associated to the fact that all intercropped systems yielded higher-production values than the nonintercropped ones (although they were not statistically significant) shows the benefit of straw produced by forage species on soybean cultivation. Similarly, Pacheco et al. (2009) confirmed that grain yield was positively affected by the presence of straw on the soil surface, which resulted in a higher-soybean yield from intercropping with $U$. ruziziensis, in comparison to fallow treatment.

Improvements in the chemical, physical, and biological characteristics of the soil due to the presence of surface straw could explain the positive effects on soybean yield observed in the intercropping trials. According to Rheinheimer et al. (1998), crop residues

Table 1. F values for the yield components of soybean (Glycine max) and dry matter weight of residues of different forage species, in the different intercroppings and agricultural seasons.

\begin{tabular}{|c|c|c|c|c|c|c|c|}
\hline Source of variation & $\begin{array}{l}\text { Plant } \\
\text { height }\end{array}$ & $\begin{array}{c}\text { Final } \\
\text { population }\end{array}$ & $\begin{array}{c}\text { Number of pods } \\
\text { per plant }\end{array}$ & $\begin{array}{c}\text { Number of } \\
\text { grains per pod }\end{array}$ & $\begin{array}{c}\text { Mass of } 100 \\
\text { grains }\end{array}$ & $\begin{array}{l}\text { Grain } \\
\text { yield }\end{array}$ & $\begin{array}{l}\text { Dry weight } \\
\text { of residues }\end{array}$ \\
\hline Cultivation system (CS) & $3.497 * *$ & $8.89^{* *}$ & $6.83 * *$ & $0.64^{\mathrm{ns}}$ & $2.21^{\mathrm{ns}}$ & $4.86^{* *}$ & $59.70 * *$ \\
\hline Agricultural season (A) & $26.209 * *$ & $0.55^{\mathrm{ns}}$ & $346.60 * *$ & $12.20 * *$ & $148.59 * *$ & $3.29^{\mathrm{ns}}$ & $87.65 * *$ \\
\hline $\mathrm{CS} \times \mathrm{A}$ & $1.809^{\mathrm{ns}}$ & $4.78 * *$ & $6.354 * *$ & $2.62 *$ & $2.04^{\mathrm{ns}}$ & $1.56^{\mathrm{ns}}$ & $4.31 * *$ \\
\hline Coefficient of variation (\%) & 12.45 & 13.57 & 11.41 & 9.08 & 8.08 & 15.86 & 22.35 \\
\hline
\end{tabular}

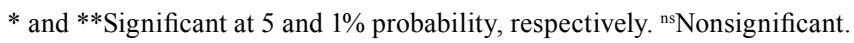


on the soil surface function as a kind of reservoir of nutrients for the next cultivation, which are released by the action of microorganisms. Furthermore, the residues improve the structural stability of the soil, thereby preventing erosion. Cultivation systems that include straw can also promote an increase of soil organic matter, also increasing the fertility of acidic soils with $\mathrm{pH}$-dependent charges associated with organic matter. According to Macedo (2009), the successful adoption of a no-tillage system is highly dependent on the production and continued presence of surface straw (Calvo et al., 2010).

The intercropped forage species ranged significantly for the amount of straw they produced, both in the first and second crop years (Table 2). The absence of the value of straw yield in the post-soybean $P$. americanum treatment is due to the failure of seed to germinate, caused by the lack of water after seed were planted (Figure 1).

Table 2. Yield components of soybean (Glycine max) for the intercroppings with Urochloa ruziziensis, Urochloa brizantha 'Marandu', Panicum maximum 'Mombaça', Panicum maximum 'Massai', and Pennisetum americanum 'ADR 300', for the crop years of 2013/2014 and 2014/2015 ${ }^{(1)}$.

\begin{tabular}{|c|c|c|c|c|c|c|}
\hline Treatment & $2013 / 2014$ & $2014 / 2015$ & Mean & $2013 / 2014$ & $2014 / 2015$ & Mean \\
\hline & \multicolumn{3}{|c|}{ Plant height $(\mathrm{cm})$} & \multicolumn{3}{|c|}{ Final population (plant $\mathrm{m}^{-1}$ ) } \\
\hline Soybean x $P$. maximum 'Massai' & 60.80 & 61.53 & $61.17 \mathrm{ab}$ & $11.21 \mathrm{ab}$ & $11.47 \mathrm{a}$ & 11.34 \\
\hline Soybean $x P$. maximum & 73.70 & 61.25 & $67.48 \mathrm{a}$ & $13.21 \mathrm{Aa}$ & $9.05 \mathrm{Ba}$ & 11.13 \\
\hline Soybean x $U$. brizantha & 63.53 & 53.00 & $58.26 \mathrm{ab}$ & $10.87 \mathrm{ab}$ & $11.47 \mathrm{a}$ & 11.17 \\
\hline Soybean $\mathrm{x} U$. ruziziensis & 59.25 & 55.40 & $57.33 \mathrm{ab}$ & 12.42 & 10.69 & 11.55 \\
\hline Soybean $\mathrm{x} P$. americanum & 64.53 & 56.20 & $60.36 \mathrm{ab}$ & $8.33 \mathrm{bc}$ & $9.69 \mathrm{a}$ & 9.01 \\
\hline Soybean followed by $P$. americanum & 59.71 & 42.76 & $51.23 b$ & $6.46 \mathrm{Ac}$ & $8.80 \mathrm{Ba}$ & 7.63 \\
\hline Soybean followed by fallow & 67.95 & 48.78 & $58.36 \mathrm{ab}$ & $10.37 \mathrm{ab}$ & $9.75 \mathrm{a}$ & 10.06 \\
\hline \multirow[t]{2}{*}{ Mean } & $64.21 \mathrm{~A}$ & 54.13B & - & 10.41 & 10.13 & - \\
\hline & \multicolumn{3}{|c|}{ Number of pods per plant } & \multicolumn{3}{|c|}{ Number of grains per pod } \\
\hline Soybean x $P$. maximum 'Massai' & $60.58 \mathrm{Abc}$ & $42.40 \mathrm{Ba}$ & 51.49 & $2.30 \mathrm{~A}$ & $1.90 \mathrm{~B}$ & 2.10 \\
\hline Soybean $x P$. maximum & $64.76 \mathrm{Abc}$ & $38.63 \mathrm{Ba}$ & 51.69 & 2.12 & 2.21 & 2.16 \\
\hline Soybean $\mathrm{x} U$. brizantha & $55.79 \mathrm{Ac}$ & $33.30 \mathrm{Ba}$ & 44.54 & $2.43 \mathrm{~A}$ & $1.96 \mathrm{~B}$ & 2.19 \\
\hline Soybean $\mathrm{x} U$. ruziziensis & $53.29 \mathrm{Ac}$ & $31.03 \mathrm{Ba}$ & 42.16 & 2.26 & 2.05 & 2.16 \\
\hline Soybean $x P$. americanum & 79.19Aa & $30.08 \mathrm{Ba}$ & 54.63 & $2.42 \mathrm{~A}$ & $2.09 \mathrm{~B}$ & 2.26 \\
\hline Soybean followed by $P$. americanum & 71.57Aab & $42.33 \mathrm{Ba}$ & 56.95 & 2.23 & 2.27 & 2.25 \\
\hline Soybean followed by fallow & $64.75 \mathrm{Abc}$ & $33.17 \mathrm{Ba}$ & 48.96 & 2.16 & 2.16 & 2.16 \\
\hline \multirow[t]{2}{*}{ Mean } & 64.27 & 35.85 & & 2.28 & 2.09 & - \\
\hline & \multicolumn{3}{|c|}{ Mass of 100 grains $(\mathrm{g})$} & \multicolumn{3}{|c|}{ Grain yield $\left(\mathrm{kg} \mathrm{ha}^{-1}\right)$} \\
\hline Soybean x $P$. maximum 'Massai' & 16.05 & 23.16 & $19.61 \mathrm{a}$ & 3,747 & 3,556 & $3,652 \mathrm{ab}$ \\
\hline Soybean $x P$. maximum & 16.44 & 22.04 & $19.24 \mathrm{a}$ & 4,319 & 4,157 & $4,238 \mathrm{a}$ \\
\hline Soybean $\mathrm{x} U$. brizantha & 16.25 & 22.38 & $19.32 \mathrm{a}$ & 3,788 & 3,529 & $3,658 \mathrm{ab}$ \\
\hline Soybean x U. ruziziensis & 17.20 & 20.96 & $19.08 \mathrm{a}$ & 3,772 & 3,091 & $3,432 \mathrm{ab}$ \\
\hline Soybean $\mathrm{x} P$. americanum & 15.84 & 20.76 & $18.30 \mathrm{a}$ & 3,740 & 2,924 & $3,332 b$ \\
\hline Soybean followed by $P$. americanum & 16.02 & 18.50 & $17.26 \mathrm{a}$ & 2,495 & 3,180 & $2,837 \mathrm{~b}$ \\
\hline Soybean followed by fallow & 16.40 & 21.02 & $18.71 \mathrm{a}$ & 3,498 & 3,044 & $3,271 \mathrm{~b}$ \\
\hline \multirow[t]{2}{*}{ Mean } & $16.32 \mathrm{~B}$ & $21.26 \mathrm{~A}$ & - & $3,623 \mathrm{~A}$ & $3,354 \mathrm{~A}$ & - \\
\hline & \multicolumn{3}{|c|}{ Straw dry weight $\left(\mathrm{kg} \mathrm{ha}^{-1}\right)$} & & & \\
\hline Soybean x $P$. maximum 'Massai' & $3,661 \mathrm{Bbc}$ & $7,838 \mathrm{Ab}$ & 5,750 & - & - & - \\
\hline Soybean $x P$. maximum & $7,571 \mathrm{Ba}$ & $11,394 \mathrm{Aa}$ & 9,483 & - & - & - \\
\hline Soybean x U. brizantha & $3,549 \mathrm{Bbc}$ & $8,159 \mathrm{Ab}$ & 5,854 & - & - & - \\
\hline Soybean x U. ruziziensis & $4,659 \mathrm{Bb}$ & $8,396 \mathrm{Ab}$ & 6,527 & - & - & - \\
\hline Soybean $\mathrm{x} P$. americanum & $1,939 \mathrm{Ac}$ & $2,149 \mathrm{Ac}$ & 2,044 & - & - & - \\
\hline Soybean followed by $P$. americanum & - & - & - & - & - & - \\
\hline Soybean followed by fallow & - & $1,948 \mathrm{c}$ & 974 & - & - & - \\
\hline Mean & 3,563 & 6,647 & - & - & - & - \\
\hline
\end{tabular}

${ }^{(1)}$ Means followed by equal letters, lowercase in the columns and uppercase in the lines, do not differ by the Tukey's test, at $5 \%$ probability. 
In the first crop year, the values of forage straw yielded by $P$. maximum 'Massai', $U$. brizantha 'Marandu', and $U$. ruziziensis differed significantly. However, these systems showed lower-straw yield than $P$. maximum 'Mombaça', which showed 3,910, 4,022, 2,912, and 5,632 $\mathrm{kg} \mathrm{ha}^{-1}$ more than $P$. maximum 'Massai', U. brizantha 'Marandu', U. ruziziensis, and $P$. americanum, respectively, in the first season (Table 2). The behavior of these systems, in the second crop year, was similar to that of the first one, and $P$. maximum 'Mombaça' showed again the highestdry matter values, which was 3,556, 3,235, 2,998, 9,245 and 9,446 kg ha-1 higher than those for the intercroppings with 'Massai', 'Marandu', U. ruziziensis, $P$. americanum, and the post-soybean $P$. americanum, respectively.

Krutzmann et al. (2013) could not verify any significant differences in straw yield, when studying tropical Poaceae species under different intercropping conditions. They attributed this result to the fact that members of this family - which have similar physiological characteristics - underwent the same techniques and management periods, and were subjected to the same climactic and soil fertility conditions. Also Garcia et al. (2014) confirmed similarities in the straw yield between Panicum and Urochloa species, which showed 13,499 $\mathrm{kg} \mathrm{ha}^{-1}$ as mean dry matter yield.

\section{Conclusions}

1. The intercropping of soybean (Glycine max) with the oversown forage species Urochloa ruziziensis, Urochloa brizantha 'Marandu', Panicum maximum 'Mombaça', Pennisetum. maximum 'Massai', and Pennisetum americanum does not reduce soybean yield.

2. The intercropping of soybean with $P$. maximum 'Mombaça' increases plant height and grain yield, in comparison with monocropped soybean.

3. Panicum maximum 'Mombaça' is the most effective forage species for dry matter yield during the fall-spring growing period.

\section{References}

CALVO, C.L.; FOLONI, J.S.S.; BRANCALIÃO, S.R. Produtividade de fitomassa e relação $\mathrm{C} / \mathrm{N}$ de monocultivos $\mathrm{e}$ consórcios de guandu-anão, milheto e sorgo em três épocas de corte. Bragantia, v.69, p.77-86, 2010. DOI: 10.1590/S000687052010000100011 .

CLAESSEN, M.E.C. (Org.). Manual de métodos de análise de solo. 2.ed. rev. e atual. Rio de Janeiro: Embrapa-CNPS, 1997. 212p. (EMBRAPA-CNPS. Documentos, 1).

CORREIA, N.M.; GOMES, L.J.P. Sobressemeadura de soja com Urochloa ruziziensis e a cultura do milho em rotação. Pesquisa Agropecuária Brasileira, v.50, p.1017-1026, 2015. DOI: 10.1590/ S0100-204X2015001100004.

COSTA, N.R. Desempenho técnico e econômico da produção de milho e sorgo para silagem e soja em sucessão em sistema irrigado de integração lavoura-pecuária no Cerrado. 2014. 226p. Tese (Doutorado) - Universidade Estadual Paulista "Júlio de Mesquita Filho", Ilha Solteira.

CRUSCIOL, C.A.C.; MATEUS, G.P.; NASCENTE, A.S.; MARTINS, P.O.; BORGHI, E.; PARIZ, C.M. An innovative crop-forage intercrop system: early cycle soybean cultivars and palisadegrass. Agronomy Journal, v.104, p.1085-1095, 2012. DOI: 10.2134/agronj2012.0002.

FARIAS, J.R.B.; NEUMAIER, N.; NEPOMUCENO, A.L. Soja. In: MONTEIRO, J.E.B.A. (Org.). Agrometeorologia dos cultivos: o fator meteorológico na produção agrícola. Brasília: Inmet, 2010. p.263-277.

FLORES, J.P.C.; CASSOL, L.C.; ANGHINONI, I.; CARVALHO, P.C. de F. Atributos químicos do solo em função da aplicação superficial de calcário em sistema de integração lavoura-pecuária submetido a pressões de pastejo em plantio direto. Revista Brasileira de Ciência do Solo, v.32, p.2385-2396, 2008. DOI: 10.1590/S0100-06832008000600017.

GARCIA, C.M. de P.; ANDREOTTI, M.; TEIXEIRA FILHO, M.C.M.; LOPES, K.S.M.; BUZETTI, S. Decomposição da palhada de forrageiras em função da adubação nitrogenada após o consórcio com milho e produtividade da soja em sucessão. Bragantia, v.73, p.143-152, 2014. DOI: 10.1590/brag.2014.016.

KLIEMANN, H.J.; BRAZ, A.J.P.B.; SILVEIRA, P.M. da. Taxas de decomposição de resíduos de espécies de cobertura em Latossolo Vermelho Distroférrico. Pesquisa Agropecuária Tropical, v.36, p.21-28, 2006.

KRUTZMANN, A.; CECATO, U.; SILVA, P.A.; TORMENA, C.A.; IWAMOTO, B.S.; MARTINS, E.N. Palhadas de gramíneas tropicais e rendimento da soja no sistema de integração lavourapecuária. Bioscience Journal, v.29, p.842-851, 2013.

MACEDO, M.C.M. Integração lavoura e pecuária: o estado da arte e inovações tecnológicas. Revista Brasileira de Zootecnia, v.38, p.133-146, 2009. Suplemento especial. DOI: 10.1590/S151635982009001300015 .

MACHADO, L.A.Z.; ASSIS, P.G.G. de. Produção de palha e forragem por espécies anuais e perenes em sucessão à soja. Pesquisa Agropecuária Brasileira, v.45, p.415-422, 2010. DOI: 10.1590/S0100-204X2010000400010.

MARCHÃO, R.L.; BALBINO, L.C.; SILVA, E.M. da; SANTOS JÚNIOR, J. de D.G. dos; SÁ, M.A.C. de; VILELA, L.; BECQUER, T. Qualidade física de um Latossolo Vermelho sob sistemas de integração lavoura-pecuária no Cerrado. Pesquisa 
Agropecuária Brasileira, v.42, p.873-882, 2007. DOI: 10.1590/ S0100-204X2007000600015.

MURAISHI, C.T.; LEAL, A.J.F.; LAZARINI, E.; RODRIGUES, L.R.; GOMES JUNIOR, F.G. Manejo de espécies vegetais de cobertura de solo e produtividade do milho e da soja em semeadura direta. Acta Scientiarum. Agronomy, v.27, p.199207, 2005. DOI: 10.4025/actasciagron.v27i2.1903.

PACHECO, L.P.; MONTEIRO, M.M. de S.; SILVA, R.F. da; SOARES, L. dos S.; FONSECA, W.L.; NÓBREGA, J.C.A.; PETTER, F.A.; ALCÂNTARA NETO, F. de; OSAJIMA, J.A. Produção de fitomassa e acúmulo de nutrientes por plantas de cobertura no cerrado piauiense. Bragantia, v.72, p.237-246, 2013. DOI: $10.1590 /$ brag.2013.041.

PACHECO, L.P.; PIRES, F.R.; MONTEIRO, F.P.; PROCÓPIO, S. de O.; ASSIS, R.L. de; CARMO, M.L. do; PETTER, F.A. Desempenho de plantas de cobertura em sobressemeadura na cultura da soja. Pesquisa Agropecuária Brasileira, v.43, p.815823, 2008. DOI: 10.1590/S0100-204X2008000700005.

PACHECO, L.P.; PIRES, F.R.; MONTEIRO, F.P.; PROCÓPIO, S.O.; ASSIS, R.L.; CARGNELUTTI FILHO, A.; CARMO, M.L.; PETTER, F.A. Sobressemeadura da soja como técnica para supressão da emergência de plantas daninhas. Planta Daninha, v.27, p.455-463, 2009. DOI: 10.1590/S010083582009000300005 .

PARIZ, C.M.; ANDREOTTI, M.; BUZETTI, S.; BERGAMASCHINE, A.F.; ULIAN, N. de A.; FURLAN, L.C.; MEIRELLES, P.R. de L.; CAVASANO, F.A. Straw decomposition of nitrogen-fertilized grasses intercropped with irrigated maize in an integrated crop-livestock system. Revista Brasileira de Ciência do Solo, v.35, p.2029-2037, 2011. DOI: 10.1590/S010006832011000600019.

RHEINHEIMER, D.S.; KAMINSKI, J.; LUPATINI, G.C.; SANTOS, E.J.S. Modificações em atributos químicos de solo arenoso sob sistema plantio direto. Revista Brasileira de
Ciência do Solo, v.22, p.713-721, 1998. DOI: 10.1590/S010006831998000400017.

SANTOS, G.G.; SILVEIRA, P.M. da; MARCHÃO, R.L.; BECQUER, T.; BALBINO, L.C. Macrofauna edáfica associada a plantas de cobertura em plantio direto em um Latossolo Vermelho do Cerrado. Pesquisa Agropecuária Brasileira, v.43, p.115-122, 2008. DOI: 10.1590/S0100-204X2008000100015.

SANTOS, H.G. dos; JACOMINE, P.K.T.; ANJOS, L.H.C. dos; OLIVEIRA, V.A. de; LUMBRERAS, J.F.; COELHO, M.R.; ALMEIDA, J.A. de; CUNHA, T.J.F.; OLIVEIRA, J.B. de. Sistema brasileiro de classificação de solos. 3.ed. rev. e atual. Brasília: Embrapa, 2013a. 353p.

SANTOS, H.P.; FONTANELI, R.S.; SPERA, S.T.; MALDANER, G.L. Rendimento de grãos de soja em diferentes sistemas de produção integração lavoura-pecuária. Revista Brasileira de Ciências Agrárias, v.8, p.49-56, 2013b. DOI: 10.5039/agraria. v8i1a2077.

SILVA, W.B.; PETTER, F.A.; LIMA, L.B. de; ANDRADE, F.R. Desenvolvimento inicial de Urochloa ruziziensis e desempenho agronômico da soja em diferentes arranjos espaciais no cerrado Mato-Grossense. Bragantia, v.72, p.146-153, 2013. DOI: 10.1590/ S0006-87052013000200006.

SOUSA, D.M.G. de; LOBATO, E. (Ed.). Cerrado: correção do solo e adubação. 2.ed. Brasília: Embrapa Informação Tecnológica; Planaltina: Embrapa Cerrados, 2004. 416p.

THOMAS, A.L.; COSTA, J.A. Estresse hídrico em soja: impacto no potencial de rendimento de grãos. In: THOMAS, A.L.; COSTA, J.A. (Org.). Soja: manejo para alta produtividade de grãos. Porto Alegre: Evangraf, 2010. p.141-175.

VILELA, L.; MARTHA JUNIOR, G.B.; MACEDO, M.C.M.; MARCHÃO, R.L.; GUIMARÃES JÚNIOR, R.; PULROLNIK, K.; MACIEL, G.A. Sistemas de integração lavoura-pecuária na região do Cerrado. Pesquisa Agropecuária Brasileira, v.46, p.1127-1138, 2011. DOI: 10.1590/S0100-204X2011001000003.

Received on December 10, 2016 and accepted on January 30, 2017

Pesq. agropec. bras., Brasília, v.52, n.10, p.861-868, oct. 2017

DOI: 10.1590/S0100-204X2017001000005 